\title{
Etonogestrel contraceptive implant (Implanon): analysis of patient compliance and adverse effects in the breastfeeding period
}

\author{
Etonogestrel gebelik önleyici implant(Implanon): Emzirme döneminde \\ hasta uyumu ve yan etkilerin analizi
}

\author{
Candan İltemir Duvan, Elif Gözdemir, İkbal Kaygusuz, Zeynep Kamalak, Nilgün Öztürk Turhan \\ Department of Obstetrics and Gynecology, Faculty of Medicine, Fatih University, Ankara, Turkey
}

\section{Abstract}

O bjective: To analyse the compliance of patients and side effects of Implanon ${ }^{\circledR}$ during breast feeding.

M aterial and M ethods: Prospective study of 61 postpartum women who chose Implanon ${ }^{\circledR}$ for long term contraception between April 2007 and December 2009. Compliance, side effects and removals were recorded.

Results: Amenorrhoea, prolonged bleeding, frequent bleeding and infrequent bleeding were reported in 20 (32\%), 13 (21\%), 4 (6.5\%) and 2 (3.2\%) patients, respectively. Non-menstrual side effects experienced by participants included; weight gain reported by 10 patients $(16 \%)$, anxiety by $6(9.8 \%)$, breast tenderness by $4(6.5 \%)$, headache by $4(6.5 \%)$, pain at the insertion site by two $(3.2 \%)$, hirstutism by two (3.2\%), acne by 1 (1.6\%), loss of libido by 1 (1.6\%), weight gain and headache by two (3.2\%), weight gain and anxiety by two (1.6\%). The mean breastfeeding period was $16 \pm 7.4$ /months. During the follow up, Implanon $®$ was removed from 24 patients (39\%).

Conclusion: If patients are well informed about its expected side effects before placement, Implanon ${ }^{\circledR}$ is well tolerated and $\mathrm{i}$ an acceptable choice for women who have recently experienced labor and are looking for long term reversible contraception.

(J Turkish-German Gynecol Assoc 2010; 11: 141-4)

Key words: Implanon, etonogestrel, postpartum contraception, breastfeeding, compliance, side effect, removal

Received: 5 April, 2010

Accepted: 5 August, 2010

\section{Introduction}

One of the most sensitive and intimate decisions made by an individual or by a couple is that of fertility control. These decisions may be more complex for the postpartum period, which is characterized by changes in women's priorities, attitudes and lifestyles. In this period, both making a choice regarding a contraceptive method and deciding the best time for initiation of contraceptive method is unclear. Breastfeeding influences the need and timing of postpartum contraception. Lactation can only serve as a contraceptive method for up to six months, but the failure of this method has been addressed in various studies $(1,2)$. Reluctance to use other methods of

\section{Özet}

Amaç: Emzirme döneminde Implanon' un hasta uyumu ve yan etkilerini analiz etmek.

Gereç ve Yöntemler: Nisan 2007 ile Aralık 2009 arasında uzun dönem korunma için Implanon' u seçen doğum yapmış 61 kadının prospektif çalışması. Uyum, yan etkiler ve implantn çıkanı Iması kaydedildi. Bulgular: Amenore, uzayan, sık veya nadir kanamalar 20 (\%32), 13 (\%21), 4 (\%6.5) and 2 (\%3.2) şeklinde tespit edildi. Deneklerde görülen non menstrual yan etkiler sırasiyla; kilo alma 10 hasta (\%16), anksiyete 6 (\%9.8), meme gerginliği 4 (\%6.5), baş ağnsı $4(\% 6.5)$, girişim yapılan yerde ağn 2 (\%3.2), hirsutizm 2 (\%3.2), akne 1 (\%1.6), libido kaybı 1 (\%1.6), kilo alma ve baş ağnsı2 (\%3.2), kilo alma ve anksiyete 1 (\%1.6) idi. Hastalann ortalama emzirme süresi $16 \pm 7.4$ ay idi. Takip süresince 24 hastadan (\%39) Implanon ${ }^{\circledR}$ çıkanldı.

Sonuç: Yerleștirilmeden önce, hastalar beklenen yan etkileri hakkında iyi bilgilendirilirse Implanon ${ }^{\circledR}$ yeni doğum yapmış uzun dönemli, geri dönüsü olan bir korunma yöntemi arayan kadınlar için tolere ve kabul edilebilir bir yöntem olabilir.

(J Turkish-German Gynecol Assoc 2010; 11: 141-4)

Anahtar kelimeler: İmplanon, etonogestrel, postpartum korunma, emzirme, uyum, yan etki, çıkarma

Geliş Tarihi: 05 Nisan 2010

Kabul Tarihi: 05 Ağustos 2010

contraception, contraceptive failure and non-use of contraceptive services are leading causes of unintended pregnancy during breastfeeding. It is well reported that pregnancy which continues to childbirth is often associated with delay of initiation of prenatal care and shorter interpregnancy intervals and may negatively influence the health of the child and mother (3-6). When choosing a method of post-partum contraception, it is important that it does not interfere with lactation or have negative effects on the infant. For contraceptive purposes, non-hormonal methods should be the first choice for breastfeeding women. However,depending on medical or personal reasons, women may desire to use a hormonal contraceptive method. In this case, the progestagen-only method 
is advised after 6 weeks postpartum. Implanon $®$ (NV Organon, Oss, The Netherlends) is a single-rod, progestogen-only contraceptive containing $68 \mathrm{mg}$ of the active compound.

In terms of hormonal methods, combined oestrogen-progestin oral contraceptives have been shown to impair milk secretion (7), whereas contraception with progestin alone, whether delivered by oral, subdermal or intrauterine routes, appears to have no deleterious effects on milk production or infant growth when used by breastfeeding women (8).

The objective of the present study was to determine compliance and the efficacy of the patients with the single-rod contraceptive implant inserted during the immediate postpartum period. To the best of our knowledge, this is the first report investigating experiences of Turkish women with Implanon ${ }^{\circledR}$ in the postpartum period.

\section{M aterial and Methods}

This cohort study was conducted between April 2005 and December 2007 at the Obstetrics and Gynaecology Department of Fatih University, Medical School, Ankara, Turkey. The study was approved by the Hospital's Ethical Committee and all participants gave verbal informed consent. All underwent physical and pelvic examinations, as well as cervical cytological screening. Sixty-one women who had recently given birth and were breastfeeding and intended to use Implanon ${ }^{\circledR}$ for long-term contraception, were included in this study.

Exclusion criteria were being a smoker, a body mass index $\left(\mathrm{BMI} \mathrm{kg} / \mathrm{m}^{2}\right) \geq 30$, a history of thromboembolic events, pelvic infection, cervical cytological abnormality or a systemic disease (diabetes mellitus, cardiovascular disease, liver disease, thyroid disease, autoimmune diseases).

Patient compliance, side effects and removals were recorded at the end of the two years. The implant was inserted in the inner aspect of the non-dominant upper arm under local anaesthesia at least 6 weeks after delivery, by the same physician. Follow up of the patients was made by scheduled appointments or contact via a telephone consultation regarding side-effects, including bleeding pattern and whether or not they continued with the Implanon ${ }^{\circledR}$. Women were informed about side effects of Implanon ${ }^{\circledR}$ before its placement. Of the 80 potential participants, 19 refused to participate. The remaining 61 women were mentally and physically healthy, and had no contraindication for Implanon $®$ use.

All patients were followed up at 3 month intervals, for at least 1 year, with regard to menstrual and non-menstrual side effects of Implanon ${ }^{\circledR}$ and compliance with Implanon ${ }^{\circledR}$. They kept a diary in which all genital bleeding and spotting episodes were mentioned. Amenorrhoea was defined as the absence of menstruation for 3 months. Recurring bleeding at $28 \pm 7$ days intervals was defined as regular bleeding. Irregular bleeding included frequent, infrequent and prolonged bleeding episodes. Frequent bleeding was defined as having more than five bleeding or spotting episodes within 3 months. Infrequent bleeding was defined as having fewer than three bleeding or spotting episodes within 3 months. Prolonged bleeding was defined as having one or more bleeding or spotting episodes within 3 months and lasting more than 14 days each.

The treatment duration was defined as the number of days elapsed between implant insertion and its removal. The extent of exposure to the implant was expressed in woman-years. A woman-year was defined as a period of 365.25 days, which corresponds to approximately 13 cycles ( $364 \mathrm{~d}$ ). The pregnancy rate was expressed as the Pearl Index (PI), which indicates the number of pregnancies per 100 woman-years of exposure. Numbers and percentages were calculated, using SPSS 13.0 for Windows.

\section{Results}

The 61 breastfeeding women were evaluated at the end of the $24^{\text {th }}$ month. The side effects and continuation were assessed during this period. The mean age of the participants was $29.95 \pm 5.04$ years (22-41). The mean BMI of the patients was 26.27 \pm 3.23 . Twenty-three patients (23/61, 37\%) were primiparous, 28 (28/61, $45 \%)$ had delivered twice, 5 (5/61, 8\%) three times, 4 (4/61, 6.5\%) four times, 1 (1/61, 1.6\%) five times. At the time Implanon ${ }^{\circledR}$ was placed, all of the patients were in the postpartum period and breastfeeding. The majority of women $(n=54,88.5 \%)$ received counseling prior to the day of the fitting. Only 7 (11.4\%) women were fitted with Implanon ${ }^{\circledR}$ on the day of the visit. The mean days of postpartum placement of Implanon was 48.12 \pm 13.192 . Former methods of contraception were RIA ( $n=21,34 \%)$, condom (20/61, 32\%), coitus interruptus (8/61, 13\%), pills (6/61, 11\%), injectables (1/61, 1\%). Five primigravid (5/61, 8.1\%) women were not using any contraceptive method.

Age, parity, previous use of contraceptive methods and time of the placement of Implanon $₫$ are summarized in Table 1.

When patients were evaluated for side effects over 2 years, amenorrhoea was reported by 20 patients (32\%), prolonged bleeding by $13,(21 \%)$, frequent bleeding by $4,(6.5 \%)$, and infrequent bleeding by 2 ( $3.2 \%$ ) as seen in Table 2 .

Non-menstrual side effects experienced by participants included; weight gain reported by 10 patients (16\%), anxiety by 6 (9.8\%), breast tenderness by 4 (6.5\%), headache by $4(6.5 \%)$, pain at the insertion site by two (3.2\%), hirstutism by two (3.2\%), acne by 1 ( $1.6 \%)$, loss of libido by 1 (1.6\%), weight gain and headache by two (1.6\%) and weight gain and anxiety by two (1.6\%) Table 3.

Contrary to the expectation from progestogen-only implant, we did not detect any weight gain at the end of the study (24 month). Furthermore, BMI demonstrated a decrease from $26.27 \pm 3.23$ to $24.54 \pm 1.06(p<0.05)$. This reduction of weight may be an attribution to the breastfeeding effect on weight. Although, the change in BMI was not statistically significant in $10(16 \%)$ patients who reported weight gain at the end of the study, only $3(4.9 \%)$ patients requested removal of Implanon ${ }^{\circledR}$ $(\mathrm{BMI}=27.01 \pm 2.17, \mathrm{P}>0.05)$.

In our study, regarding continuation rates of Implanont at 6 months after insertion, $(n=56) 91 \%$ of women continued, ( $n=47$ ) $77 \%$ continued for 1 year, $(n=40) 65 \%$ continued for 18 month and $(n=37) 60 \%$ continued for 2 years. During the follow up, Implanon ${ }^{\circledR}$ was removed from 24 patients (39\%). The indications for removals were frequent/prolonged bleeding in eleven patients (18\%), anxiety in two $(3.2 \%)$, weight gain in three (4.9\%), pain at the insertion site in two (3.2\%), breast tenderness in two (3.2\%), hirsutism in one (1.6\%), and weight gain and anxiety in three (4.9\%). Reasons for removal of Implanon ${ }^{\circledR}$ are listed in Table 3. No problems were encountered during the placement or removal of the implant. The mean breastfeeding period of patients was $16 \pm 7.4$ /months. 
Table 1. Baseline characteristic of patients and time of placement of Implanon

\begin{tabular}{|c|c|}
\hline Characteristics & no. (\%) \\
\hline \multicolumn{2}{|l|}{ Age } \\
\hline 20-30 years & 37 \\
\hline $31-40$ years & 23 \\
\hline$>41$ year & 1 \\
\hline \multicolumn{2}{|l|}{ Parity } \\
\hline 1 & 23 \\
\hline 2 & 28 \\
\hline 3 & 5 \\
\hline 4 & 4 \\
\hline 5 & 1 \\
\hline BMI $\left(\mathrm{kg} / \mathrm{m}^{2}\right)$ & $26.27 \pm 3.23$ \\
\hline Postpartum placement (day) & $48.19 \pm 13.19$ \\
\hline Breastfeeding period of patients (month) & $16 \pm 7.4$ \\
\hline
\end{tabular}

Table 2. B leeding patterns of subjects during treatment with Implanon

\begin{tabular}{|l|c|c|}
\hline & $\mathbf{n}$ & $\%$ \\
\hline Amenorrhoea & 20 & 32 \\
\hline Prolonged bleeding & 13 & 21 \\
\hline Frequent bleeding & 4 & 6.5 \\
\hline Infrequent bleeding & 2 & 3.2 \\
\hline
\end{tabular}

Table 3. Non-menstrual side effects during I mplanon use, reasons for removal of Implanon

Side effects

\begin{tabular}{|l|l|}
\hline Weight gain & $10(16 \%)$ \\
\hline Nervousness & $6(9.8 \%)$ \\
\hline Headache & $4(6.5 \%)$ \\
\hline Breast tendernass & $4(6.5 \%)$ \\
\hline Acne & $1(1.6 \%)$ \\
\hline Loss of libido & $1(1.6 \%)$ \\
\hline Pain at the insertion site & $2(3.2 \%)$ \\
\hline Hirsutism & $2(3.2 \%)$ \\
\hline Reasons for removal & $11(18 \%)$ \\
\hline Frequent and prolonged bleeding & $3(4.9 \%)$ \\
\hline Weight gain & $2(3.2 \%)$ \\
\hline Anxiety & $3(4.9 \%)$ \\
\hline Weight gain and nervousness & $2(3.2 \%)$ \\
\hline Breast tendernass & $2(3.2 \%)$ \\
\hline Pain at the insertion site & $1(1.6 \%)$ \\
\hline Hirsutism &
\end{tabular}

During the study period, which comprised 730.5 woman-years of observation, no pregnancies occurred (Pearl index score $=0$ ).

\section{Discussion}

The postpartum period presents an increased risk of pregnancy in the life of women. It is of great importance to the new mother that the next pregnancy is postponed. Women are more likely to report pregnancies as unplanned/untimed when they occur within an interval of 24 months or less. The World Health Organization (WHO) recommends a minimum of 2 years interval between pregnancies to reduce the incidence of maternal and fetal risks in each pregnancy (9). According to our study, Implanon ${ }^{\circledR}$ is a useful choice in women who desired a longterm and reliable contraception after postpartum period.

Since Implanon ${ }^{\circledR}$ is a progestogen-only contraceptive, it is not surprising that menstrual anomalies are more frequent than during spontaneous menstrual cycles. To our knowledge, this is the first report investigating compliance and side effects of Implanon $₫$ inserted during the postpartum period in Turkish women. The present study indicated that Implanon $₫$ provided an excellent contraceptive cover for the full period of 2 years to women of a wide range of ages and weights. No pregnancies occurred in the two years of use.

Normally the most frequent side effects of Implanon ${ }^{\circledR}$ were related to the disturbed bleeding pattern. Our report showed that, like spontaneous menstrual cycles, Implanon $\AA$ is associated with disturbed bleeding pattern in breastfeeding women. In our study, when patients were evaluated for menstrual irregularity over 2 years, amenorrhoea (32\%) was the most common problem reported for these women in the first 12 months after weaning. Prolonged or frequent bleedings were infrequent in the first 12 months after treatment initiation but the proportion of bleedings lasting more than 10 days was increased after 12 months. Irregular bleeding occured in $30 \%$ of our patients after 12 months. Although the incidence of amenorrhoea was just below $20 \%$ during most of the time, this rate was increased to $32 \%$ in our patients in whom Implanon $₫$ was inserted in the early postpartum period. This can be related with the effect of breastfeeding on the menstrual cycle. It is well known that elevated levels of prolactin that occur with breastfeeding inhibit the pulsatile secretion of gonadotropin-releasing hormone from the hypothalamus. This in turn interferes with the hypothalamic- pituitary- ovarian axis, preventing estrogen secretion and ovulation (10).

No unexplained adverse maternal effects have been reported during use of Implanon ${ }^{\circledR}$ in the postpartum period (11).

In clinical trials, the most common non-menstrual side effects experienced when wearing an implant are reported to range from $15-25 \%$ (12-15). In our study, the most frequent non-menstrual side effects experienced when wearing an implant, are; weight increases, anxiety, breast tenderness and headache ( 6.5 to $16 \%$ ). Pain at the insertion site, hirstutism, acne and loss of libido are less frequently reported (1.6-3.2\%).

The mean time of implanon removal after insertion was $15.14 \pm 7.21$ month. A study of 329 users of Implanon ${ }^{\circledR}$ in Scotland (16) used 2 years 9 months as an end point and reported a comparable continuation rate of $47 \%$ of women with implant at that point. A study by Harvey et al. from family planning clinics in Queensland, Australia reported their continuation rates of Implanon at 6 months after insertion as; 
$94 \%$ of women continued, $74 \%$ continued for 1 year and $50 \%$ continued for 2 years (17). Our continuation rates in this Turkish study of $77 \%$ for 1 year and $60 \%$ for 2 years are consistent with findings from a review of evidence from UK and Europe, which concluded that $20-25 \%$ and up to $44 \%$ of women will discontinue within 1 year and 2 years, respectively (18). Another study from Spain reported similar continuation rates (91.0\%) in a follow-up of 372 women at 1 year after insertion of implanon (19). From Turkey, a study by Gezginç et al. (13) also reported that $75 \%$ of patients used Implanon ${ }^{\circledR}$ for at least 1 year of follow-up and $25 \%$ patients requested removal of the implant. Contrary to our high continuation rates at 6 months, Ylldızbaş et al. reported the high discontinuation rates (19.5\%) among women in eastern Turkey after 6 months of use of this contraceptive modality. In terms of mood changes and weight gain, they also reported a significantly increased frequency of headache, nausea and dizziness at the end of the study. Probably these differencescan be related to a different patient profile of healthy sexually active women and the short period of their study (12).

The main reason for removal during the breastfeeding period was the bleeding problem (frequent/prolonged bleeding). The most common non-menstrual side effects leading to removal were weight gain and anxiety together (20-22). Similary, in our study, the most common indications for removal were frequent/prolonged bleeding (18\%). Given the frequency of side effects such as mood changes and weight gain in the patients with Implanon ${ }^{\circledR}$ during breastfeeding period these symptoms should be specifically discussed with women, as different women may give a different level of priority when choosing a method of contraception, especially the postpartum period because, in the postpartum period, women may be more receptive to changing their contraceptive after delivery. Cwiak et al.'s study showed that (23) over $40 \%$ of peripartum women indicated a desire to change their methods.

Although prolonged breastfeeding is encouraged in Turkey, breastfeeding patterns and bottle supplementation are different among individuals. Hence, the postpartum period presents an increased risk of unplanned pregnancies. Introducing of new reliable contraceptive method such as Implanon ${ }^{\circledR}$ in the postpartum period may prevent unintended pregnancy. In our study, most of the patients ( $65 \%)$ were not aware of Implanon ${ }^{\circledR}$ as a contraceptive choice. As far as we know, there is no survey of the knowledge, attitudes and practices of postpartum contraception in Turkey. Our study is based on a small number of patients experience with Implanon ${ }^{\circledR}$ which was inserted during the postpartum period, but to the best of our knowledge no data exists about postpartum compliance and side effects of Implanon ${ }^{\circledR}$ in Turkish women. Our study also has no control group, hence the performance of Implanon ${ }^{\circledR}$ cannot be compared with the performance of other contraceptive methods during the breastfeeding period.

In conclusion, despite the frequency of side effects, a high proportion of women still use Implanon ${ }^{\circledR}$ as a method of contraception at the end of 2 years. This demonstrates that Implanon ${ }^{\circledR}$ is well tolerated and is an acceptable choice for women who have had a recent birth and are searching for a long term reversible contraception.

\section{Conflict of interest}

No conflict of interest is declared by authors.

\section{R eferences}

1. Pérez A, Labbok MH, Queenan JT. Clinical study of the lactational amenorrhoea method for family planning. Lancet. 1992; 339: 968-70.

2. Díaz S, Aravena R, Cárdenas H, Casado ME, Miranda P, Schiappacasse $\mathrm{V}$, et al. Contraceptive efficacy of lactational amenorrhea in urban Chilean women. Contraception. 1991; 43: 335-52.

3. Conde-Agudelo A, Rosas-Bermudez A, Kafury-Goeta AC. Birth spacing and risk of adverse perinatal outcomes: A meta-analysis. J AMA 2006; 295: 1809-23.

4. DaVanzo J, Hale L, Razzaque A, Rahman M. E ffects of interpregnancy interval and outcome of the preceding pregnancy on pregnancy outcomes in Matlab, Bangladesh. BJ OG 2007; 114: 1079-87.

5. DeFranco EA, Stamilio DM, Boslaugh SE, Gross GA, Muglia LJ. A short interpregnancy interval is a risk factor for preterm birth and its recurrence. Am J Obstet Gynecol 2007; 197: 264.e1-6.

6. Conde-Agudelo A, Rosas-Bermudez A, Kafury-Goeta AC. Effects of birth spacing on maternal health: A systematic review. Am J Obstet Gynecol 2007; 196: 297-308.

7. Peralta O, Díaz S, Juez G, Herreros C, Casado ME, Salvatierra AM, et al. Effect of a combined oral contraceptive on lactation and growth of the infant. Rev Chil Obstet Ginecol. 1983; 48: 372-80.

8. Faculty of Family Planning \& Reproductive Health Care. FFPRHC Guidance (July 2004): Contraceptive choices for breastfeeding women. J Fam Plann Reprod Health Care 2004; 30: 181-9.

9. World Health Organization. Department of Making Pregnancy Safer and Department of Reproductive Health and Research. Report of a WHO. Technical Consultation on Birth Spacing. Geneva: WHO; 2005.

10. Díaz S, Miranda P, Brandeis A, Cárdenas H, Croxatto HB. Mechanism of action of progesterone as contraceptive for lactating women. Ann N Y Acad Sci. 1991; 626:11-21.

11. Brito MB, Ferriani RA, Quintana SM, Yazlle ME, Silva de Sá MF, Vieira CS. Safety of the etonogestrel-releasing implant during the immediate postpartum period: a pilot study. Contraception. 2009; 80: 519-26.

12. Yildizbas B, Sahin HG, Kolusari A, Zeteroglu S, Kamaci M. Side effects and acceptability of Implanon: a pilot study conducted in eastern Turkey. Eur J Contracept Reprod Health Care. 2007; 12: 248-52.

13. Gezginc K, Balci O, Karatayli R, Colakoglu MC. Contraceptive efficacy and side effects of Implanon. Eur J Contracept Reprod Health Care. 2007; 12: 362-5.

14. Blumenthal PD, Gemzell-Danielsson K, Marintcheva-Petrova M. Tolerability and clinical safety of Implanon. Eur J Contracept Reprod Health Care. 2008; 13 Suppl 1: 29-36.

15. Brache V, Faundes A, Alvarez F, Cochon L. Nonmenstrual adverse events during use of implantable contraceptives for women: Data from clinical trials. Contraception 2002; 65: 63-74.

16. Lakha F, Glasier AF. Continuation rates of Implanon in the UK: data from an observational study in a clinical setting. Contraception 2006; 74: 287-9.

17. Harvey C, Seib C, Lucke J. Continuation rates and reasons for removal among Implanon users accessing two family planning clinics in Queensland, Australia. Contraception. 2009; 80: 527-32.

18. National Collaborating Centre for Women's and Children's Health. Long-acting reversible contraception: the effective and appropriate useof long-acting reversible contraception. London: RCOG Press; 2005.

19. Arribas-Mir L, Rueda-Lozano D, Agrela-Cardona M, Cedeño-Benavides T, Olvera-Porcel C, Bueno-Cavanillas A. Insertion and 3-year follow-up experience of 372 etonogestrel subdermal contraceptive implants by family physicians in Granada, Spain. Contraception. 2009; 80: 457-62.

20. Sergent F, Clamageran C, Bastard AM, Verspyck E, Marpeau L. ACceptability of the etonorgestrel-containing contraceptive implant (Implanon). J Gynecol Obstet Biol Reprod 2004; 33: 407-15.

21. Rai K, Gupta S, Cotter S. Experience with Implanon in a north-east London family planning clinic. Eur J Contracep Reproduc Health Care 2004; 9: 39-46.

22. Reuter S, Smith A. Implanon: user views in the first year across three family planning services in the Trent Region, UK. Eur J Contracep Reproduc Health Care 2003; 8: 27-36.

23. Cwiak C, Gellasch T, Zieman M. Peripartum contraceptive attitudes and practices. Contraception. 2004; 70: 383-6. 